\title{
PERBEDAAN HASIL BELAJAR SISWA MENGGUNAKAN MODEL DIRECT INSTRUCTION DAN MODEL INKUIRI PADA MATA PELAJARAN IPA KELAS V SDN 101816 PANCUR BATU TAHUN PEMBELAJARAN 2018/2019
}

\author{
OLEH: \\ ANGELIA KEKE BEGITA KEMBAREN \\ (PGSD FKIP UNIVERSITAS KATOLIK SANTO THOMAS SU)
}

\begin{abstract}
ABSTRACKT
This Research aims to find out the differences of direct instruction model and inquiry model in improving learning outcomes of the fifth grade students on science subject with material objects and properties of objects at SDN 101816 Pancur Batu in academic year 2018/2019. The number of students population at SDN 101816 Pancur Batu in academic year 2018/2019 are 534 students. This sample taken by sampling purposive 66 students. The model used in the study is an experimental model is one-group pretest-posttest design.The model in this study uses experiments conducted in two groups, namely experiment I and experiment II. The instrument used to capture data is multiple choice tests in material objects and their properties.

Based on statistical data processing in group I obtained the average results that is 73.23 , standard deviation 6,85 and standard error 1.19 out of 34 students. For the experimental group II, the average results were 86.56, standard deviation was 6.55 and the standard error was 1.17 from the total 32 students. By using the "t" test, it was obtained to $=7.949$ and then consulted with the table that is $\mathrm{dk}=66$ at a significant level of $5 \%=1.99$. Therefore, the obtained to be greater than $t$ table is 7,949 the null hypothesis (Ho) is rejected and the alternative hypothesis $\left(\mathrm{H}_{1}\right)$ is accepted. This proves that the Inquiry model is better than the Direct Instruction model of material objects and their properties. Therefore, it can be concluded that the Inquiry model is more effective than the Direct Instruction model of material objects and their properties the fifth grade students of SDN 101816 Pancur Batu academic year 2018/2019.
\end{abstract}

Keywords: Differences, Direct Instruction Models, Inquiry, Objects and Nature Models

\section{PENDAHULUAN}

\section{Latar Belakang Masalah}

Pendidikan adalah salah satu bentuk perwujudan kebudayaan manusia yang dinamis dan sarat perkembangan. Oleh karena itu perubahan atau perkembangan pendidikan adalah hal yang memang seharusnya terjadi sejalan dengan perubahan budaya kehidupan. Perubahan dalam arti perbaikan pendidikan pada semua tingkat perlu terus menerus dilakukan sebagai antisipasi kepentingan masa depan dan tuntutan masyarakat modern. Sebagaimana tercantum dalam 
Undang-Undang Republik Indonesia Nomor 20 Tahun 2003 Pasal 1 tentang Sistem Pendidikan Nasional menjelaskan pendidikan adalah usaha sadar dan terencana untuk mewujudkan suasana belajar dan proses pembelajaran agar peserta didik secara aktif mengembangkan potensi dirinya untuk memiliki kekuatan spiritual keagamaan, pengendalian diri, kepribadian, kecerdasan, akhlak mulia, serta keterampilan yang diperlukan dirinya, masyarakat, bangsa dan negara.

Undang-Undang Republik Indonesia Nomor 20 Tahun 2003 pasal 3 Pendidikan nasional berfungsi mengembangkan kemampuan dan membentuk watak serta peradaban bangsa bermartabat dalam rangka mencerdaskan kehidupan bangsa, bertujuan untuk berkembangnya potensi peserta didik agar menjadi manusia yang beriman, bertakwa kepada Tuhan Yang Maha Esa, berakhlak mulia, sehat, berilmu, cakap, kreatif, mandiri, dan menjadi warga negara yang demokratis serta bertangggung jawab. Agar tujuan pendidikan dapat tercapai sesuai dengan rencana dibutuhkan peraturan mengenai pendidikan yaitu kurikulum. Sebagaimana tertuang dalam pasal 1 ayat 19 Undang-Undang No 20 Tahun 2003, kurikulum adalah seperangkat rencana dan pengaturan mengenai tujuan, isi, dan bahan pelajaran serta cara yang digunakan sebagai pedoman penyelenggaraan kegiatan pembelajaran untuk mencapai tujuan pendidikan tertentu.

Ada sejumlah mata pelajaran dalam kurikulum pembelajaran di sekolah mulai dari pendidikan dasar, menengah, dan pendidikan tinggi. Mata pelajaran tersebut dapat mengubah hidup pembelajar di sekolah dasar misalnya ada mata pelajaran sains (Ilmu Pengetahuan Alam), Ilmu Pengetahuan Sosial, Matematika, Bahasa, mata pelajaran yang berkaitan dengan pengembangan karakter, dan mata pelajaran keterampilan. Ilmu Pengetahuan Alam (IPA) merupakan mata pelajaran yang mengajak siswa untuk berpikir kritis dan dapat mengalami pembelajaran dalam dunia nyata.

Guru adalah pendidik dan pengajar pada pendidikan anak usia dini jalur sekolah atau pendidikan formal, pendidikan dasar, dan pendidikan menengah. Guru-guru seperti ini harus mempunyai semacam kualifikasi formal. 
Dalam definisi yang lebih luas, setiap orang yang mengajarkan suatu hal yang baru dapat juga dianggap seorang guru. Dalam hal ini guru lah yang memberikan ilmu kepada siswa mengenai segala sesuatu yang belum mereka ketahui.

Mata pelajaran IPA merupakan mata pelajaran yang selama ini dianggap sulit oleh sebagian besar peserta didik, mulai dari jenjang sekolah dasar sampai sekolah menegah. Pada saat pembelajaran IPA dilakukan di kelas, kerap kali ditemukan hasil belajar yang tidak maksimal. Hal ini dapat dapat dikaitkan dengan banyak hal yang mempengaruhi hasil belajar IPA, misalnya faktor siswa (seperti kesiapan, sikap, minat, bakat, dan tingkat inteligensi), faktor guru (seperti penguasaan materi, strategi, metode, pendekatan, dan media), faktor kurikulum dengan susunan dan strukturnya, faktor lingkungan, serta faktor orangtua.

Dalam KTSP mata pelajaran IPA di SD/MI bertujuan agar peserta didik memiliki kemampuan sebagai berikut: 1) memperoleh keyakinan terhadap kebesaran Tuhan Yang Maha Esa berdasarkan keberadaan, keindahan dan keteraturan alam ciptaan-Nya; 2) mengembangkan pengetahuan dan pemahaman konsep-konsep IPA yang bermanfaat dan dapat diterapkan dalam kehidupan sehari-hari; 3) mengembangkan rasa ingin tahu yang saling mempengaruhi antara IPA, lingkungan, teknologi dan masyarakat; 4) mengembangkan keterampilan proses untuk menyelidiki alam sekitar, memecahkan masalah dan membuat keputusan. Dari tujuan tersebut maka tugas seorang pendidik adalah bagaimana menerapkan beberapa ketrampilan mengajar agar seluruh tujuan tersebut dapat tercapai dalam mata pelajaran IPA. Selain itu, pembelajaran IPA juga memberikan pengetahuan dasar dari konsep yang bermanfaat untuk kehidupan sehari-hari.

Tujuan yang terkandung dalam KTSP tersebut sudah mengandung ide-ide yang dapat mengantisipasi perkembangan IPTEK secara global. Namun kenyataan dilapangan tidak sejalan dengan tujuan pada kurikulum, seperti temuan di lapangan tentang pembelajaran IPA di sekolah dasar antara lain, guru belum melaksanakan pembelajaran yang dapat menumbuhkan kemampuan berfikir, kerja dan bersikap ilmiah bagi peserta didik dalam pembelajarannya guru memberikan siswa dengan sejumlah konsep yang bersifat hafalan belaka. Dengan demikian, 
siswa tidak memahami dasar kualitatif tentang fakta-fakta dalam materi serta tingkat pemahaman semakin berkurang sehingga pada kenyataanya timbul kebosanan pada siswa, tujuan siswa agar menguasai konsep yang diajarkan justru tidak tercapai. Kondisi seperti itu ditemukan juga pada pembelajaran IPA, yaitu guru berusaha agar siswa mampu menghafal materi sebanyak mungkin sesuai yang diterangkan oleh guru. Dalam hal ini, yang terjadi adalah pembelajaran berpusat pada guru dan bersifat satu arah, sehingga siswa kurang mandiri dalam belajar bahkan siswa menjadi cenderung pasif dan kurang aktif.

Berdasarkan observasi yang dilakukan oleh peneliti pada mata pelajaran IPA di SD Negeri 101816 Pancur batu, metode pembelajaran yang dilakukan oleh guru adalah metode ceramah, sehingga siswa mudah bosan dalam mengikuti proses pembelajaran dan pada siswa kurangnya kerja sama.Pada umumnya masalah yang dihadapai di SD Negeri 101816 Pancur Batu dalam pembelajaran IPA adalah metode guru dalam mengajar yang kurang bervariasi. Hal ini tampak terutama dalam pembelajaran IPA, guru cenderung menggunakan metode ceramah, akhirnya siswa kurang paham dengan hanya penjelasan saja yang diberikan oleh guru. Masalah lain berkaitan dengan kurangnya fasilitas dan sarana yang dibutuhkan, kejenuhan siswa belajar karena situasi belajar yang berpusat pada guru, rendahnya minat belajar siswa, guru yang berperan sangat dominan dalam kegiatan pembelajaran sehingga siswa tidak diberikan kesempatan untuk melakukan tukar pikiran dengan teman sebangkunya.

IPA diperlukan dalam kehidupan sehari-hari untuk memenuhi kebutuhan manusia melalui pemecahan masalah-masalah yang dapat diidentifikasikan. Penerapan IPA perlu dilakukan secara bijaksana agar tidak berdampak buruk padalingkungan. Pembelajaran IPA sebaiknya dilakukan dengan Model Direct Instruction (model pembelajaran langsung) dan Model Pembelajaran Inkuiri (inquiry) untuk menumbuhkan kemampuan berpikir, bekerja dan bersikap ilmiah serta mengkomunikasikannya sebagai aspek penting kecakapan hidup. Oleh karena itu pembelajaran IPA di SD/MI menekankan pada pemberian pengalaman belajar secara langsung melalui penggunaan dan pengembangan keterampilan proses dan sikap ilmiah. 
Peneliti mengobservasi dua lokal yang ada di SDN 101816 Pancur Batu yaitu kelas V-A dan V-B. Daftar nilai yang bersumber dari wali kelas V-A dan VB. Untuk mengetahui tingkat ketuntasan setiap siswa, diawal tahun ajaran oleh satuan pendidikan berdasarkan hasil musyawarah guru mata pelajaran di satuan pendidikan menetukan Kriteria Ketuntasan Minimal (KKM). Dan untuk mata pelajaran IPA di SDN 101816 Pancur batu adalah 65. Untuk lebih jelas dapat kita lihat pada tabel berikut.

Tabel 1.1 Transkip Nilai siswa kelas V-A Tahun Pembelajaran 2017/2018

\begin{tabular}{|l|l|l|l|l|}
\hline KKM & Nilai Siswa & Frekuensi & Persentase & Kriteria \\
\hline \multirow{3}{*}{ Junlah } & $\mathrm{N}<65$ & 28 orang & $82,4 \%$ & Tidak Tuntas \\
\cline { 2 - 5 } & $\mathrm{N}>65$ & 6 orang & $17,6 \%$ & Tuntas \\
\hline
\end{tabular}

Sumber: SD Negeri 101816 Pancur Batu

Pada tabel diatas dapat kita lihat nilai yang diperoleh siswa kelas V-A, pada nilai kurang dari 65 terdapat 28 orang siswa dan nilai lebih dari 65 terdapat 6 orang siswa. Berdasarkan ketentuan KKM maka nilai yang berada diatas 65 dinyatakan tuntas yaitu 17,6\% dan nilai yang berada di bawah 65 yaitu $82,4 \%$.

Tabel 1.2 Transkip Nilai siswa kelas V-B Tahun Pembelajaran 2017/2018

\begin{tabular}{|l|l|l|l|l|}
\hline KKM & Nilai Siswa & Frekuensi & Persentase & Kriteria \\
\hline \multirow{3}{*}{ Jumlah } & $\mathrm{N}<65$ & 19 orang & $59,4 \%$ & Tidak Tuntas \\
\cline { 2 - 5 } & $\mathrm{N}>65$ & 13 orang & $40,6 \%$ & Tuntas \\
\hline
\end{tabular}

Sumber: SD Negeri 101816 Pancur Batu

Pada tabel diatas dapat kita lihat nilai yang diperoleh siswa kelas V-B, pada nilai kurang dari 65 terdapat 19 orang dan nilai lebih dari 65 terdapat 13 orang. Berdasarkan ketentuan KKM maka nilai yang berada diatas 65 dinyatakan tuntas yaitu 40,6\% dan yang berada dibawah 65 yaitu $59,4 \%$. 
Untuk memperoleh hasil belajar yang lebih baik salah satu upaya yang dilakukan ialah dengan menggunakan model pembelajaran. Menurut Joice dan Weil (2014:48), mendefinisikan model pembelajaran sebagai suatu pola atau rencana yang sudah direncanakan sedemikian rupa dan digunakan untuk menyusun kurikulum, mengatur materi pelajaran, dan memberi petunjuk pada pembelajaran dikelas. Menurut peneliti ada banyak model pembelajaran tapi yang lebih cocok dan dominan ialah dua model pembelajaran yang dapat diterapkan dalam pembelajaran IPA untuk materi pelajaran tertentu, misalnya dalam mengajarkan materi benda dan sifatnya, yaitu model Direct Instruction dan inkuiri.

Tampubolon (2014:89) menjelaskan bahwa pembelajaran langsung (direct instruction) merupakan pembelajaran yang berpusat pada pendidik (teacher center)dengan teknik pembelajaran ekspositori, yaitu pemindahan pengetahuan dari pendidik kepada peserta didik secara langsung. Model pembelajaran ini dirancang untuk menciptakan lingkungan belajar terstruktur dan berorientasi pada pencapaian akademik.

Sedangkan, Kurniasih dan Sani (2015:113) menjelaskan model pembelajaran inkuiri merupakan pembelajaran dengan seni merekayasa situasisituasi yang sedemikian rupa sehingga siswa bisa berperan sebagai ilmuan. Siswa diajak untuk bisa memiliki inisiatif untuk mengamati dan menanyakan gejala alam, mengajukan penjelasan-penjelasan tentang apa yang mereka lihat, merancang dan melakukan pengujian untuk menunjang atau menentang teori-teori mereka, menganalisis data, menarik kesimpulan dari data eksperimen, merancang dan membangun model.

Model pembelajaran inkuiri merupakan strategi yang berpusat langsung pada diri peserta didik. Dimana peserta didik dibagi dalam beberapa kelompok, kemudian guru menyajikan berbagai masalah yang sesuai dengan materi benda dan sifatnya, sehingga peserta didik dapat saling bertukar pikiran, mengungkapkan berbagai ide kreatif dan berusaha saling memahami pendapat yang telah diutarakan oleh masing - masing peserta didik dalam kelompok, sementara guru bertindak sebagai fasilitator yang mengarahkan peserta didik 
untuk menyelidiki dan dapat menarik kesimpulan untuk setiap masalah yang disajikan oleh guru.

Berdasarkan pada latar belakang masalah yang diuraikan diatas, maka peneliti bermaksud mengadakan penelitian dengan mengambil judul“" Perbedaan Hasil Belajar Siswa Menggunakan Model Direct Instruction Dan Model Inkuri Pada Mata Pelajaran IPA Kelas V SDN 101816 Pancur Batu Tahun Pembelajaran 2018/2019"

\section{Identifikasi Masalah}

Berdasarkan latar belakang di atas dapat disimpulkan identifikasi masalah adalah sebagai berikut.

1. Guru masih menggunakan model pembelajaran konvensional

2. Guru kurang mampu menggunakan model pembelajaran yang bervariasi

3. Siswa kurang berpartisipasi secara aktif dalam pembelajaran dikelas

4. Suasana pembelajaran yang dialami siswa membosankan

5. Hasil nilai siswa yang rendah

\section{Pembatasan Masalah}

Berdasarkan identifikasi masalah yang telah disebutkan, perlu pembatasan masalah agar penelitian ini lebih fokus dan terarah yaitu Perbedaan Hasil Belajar Siswa Menggunakan Model Direct Instruction Dan Model Inkuri Pada Mata Pelajaran IPA pada materi Benda dan Sifatnya Kelas V SDN 101816 Pancur Batu Tahun Pembelajaran 2018/2019.

\section{Perumusan Masalah}

Berdasarkan batasan masalah di atas, masalah-masalah yang akan diteliti dapat di rumuskan sebagai berikut :

1. Bagaimana hasil belajar siswa kelas V dengan menggunakan Model Direct Instruction pada mata pelajaran IPA pada materi benda dan sifatnya di SDN 101816 Pancur Batu Tahun Pembelajaran 2018/2019?

2. Bagaimana hasil belajar siswa kelas V dengan menggunakan Model Inkuiri pada mata pelajaran IPA pada materi benda dan sifatnya di SDN 101816 Pancur Batu Tahun Pembelajaran 2018/2019? 
3. Apakah ada perbedaan penerapan model Direct Instruction dan Inkuiri dengan hasil belajar IPA siswa kelas V pada materi benda dan sifatnya di SDN 101816 Pancur Batu Tahun Pembelajaran 2018/2019?

\section{Tujuan Penelitian}

Berdasarkan batasan masalah dan rumusan masalah di atas maka tujuan penelitian ini adalah :

1. Untuk mengetahui hasil belajar siswa kelas V pada mata pelajaran IPA pada materi benda dan sifatnya dengan menggunakan model Direct Instruction di SDN 101816 Pancur Batu Tahun Pembelajaran 2018/2019.

2. Untuk mengetahui hasil belajar siswa pada mata pelajaran IPA pada materi benda dan sifatnya dengan menggunakan model Inkuiri Siswa kelas V di SDN 101816 Pancur Batu Tahun Pembelajaran 2018/2019.

3. Untuk mengetahui perbedaan penerapan model pembelajaran Direct Instruction dan Inkuiri dengan hasil belajar IPA siswa kelas V pada materi benda dan sifatnya di SDN 101816 Pancur Batu Tahun Pembelajaran $2018 / 2019$.

\section{Manfaat Penelitian}

Hasil penelitian yang diharapkan dapat memberikan manfaat secara teoritis dan praktis kepada berbagai pihak antara lain:

\section{Manfaat Teoritis}

Penelitian ini diharapkan dapat memberikan masukan bagi dunia pendidikan. Serta memberi gambaran mengenai penggunaan model pembelajaran Direct Instruction dan model pembelajaran Inkuiri untuk meningkatkan belajar yang efektif bagi siswa dalam pelajaran IPA disekolah dasar.

2. Manfaat Praktis

a. Manfaat untuk guru

Memberikan motivasi terhadap guru dalam memilih model dalam pembelajaran yang tepat pada materi pelajaran di setiap mata pelajaran.

b. Manfaat untuk siswa

Menjadikan siswa lebih kreatif dan inovatif serta meningkatkan motivasi siswa dalam pelajaran. 
c. Manfaat untuk sekolah

Penelitian ini diharapkan bermanfaat untuk meningkatkan mutu pendidikan di sekolah serta memotivasi guru dalam melakukan pembelajaran.

d. Manfaat bagi peneliti

Menambah wawasan peneliti dalam berpikir dan mengembangkan model pembalajaran yang tepat pada materi pelajaran di setiap mata pelajaran.

\section{METODOLOGI PENELITIAN}

\section{Pendekatan dan Metode Penelitian}

Dalam penelitian, setiap penelitian terlebih dahulu harus menentukan metode/jenis penelitian yang digunakan.Metode ataupun jenis penelitian sangat berperan penting, karena sebagai kegiatan yang dilakukan dalam upaya menentukan dan membuktikan sesuatu sepenuhnya tergantung kepada metode yang digunakan oleh peneliti.Adapun metode penelitian yang digunakan dalam penelitian ini adalah metode eksperimen dengan jenis penelitian kuantitatif. Sugiyono (2017:14) metode penelitian kuantitatif dapat diartikan sebagai metode yang berlandaskan pada filsafat positivisme, digunakan untuk meneliti pada populasi atau sampel tertentu, teknik pengambilan sampel yang digunakan adalah sampling purposive, pengumpulan data menggunakan instrumen penelitian, analisis data bersifat kuantitatif/statistik dengan tujuan untuk menguji hipotesis yang telah ditetapkan.

\section{Tempat, Kegiatan dan Waktu Penelitian}

\section{Tempat Penelitian}

Penelitian ini dilakukan di SDN 101816 Pancur Batu pada siswa kelas V tahun pembelajaran 2018/2019. Adapun pemilihan tempat tersebut sebagai lokasi penelitian didasari pertimbangan sebagai berikut:

1. Jumlah siswa di SDN 101816 Pancur Batu cukup memadai untuk dijadikan subjek penelitian yaitu 66 siswa.

2. Di SDN 101816 Pancur Batu belum pernah dilakukan penelitian seperti ini. 
3. Di SDN 101816 peneliti mendapat izin untuk penelitian

\section{Waktu dan Kegiatan Penelitian}

Penelitian ini dilaksanakan pada semester ganjil tahun pembelajaran $2018 / 2019$.

\section{Rancangan/Desain Penelitian}

Desain penelitian yang digunakan adalah metode pre-experimental design. Menurut Nurhayat (2016: 41-42) Bentuk desain penelitian yang akan digunakan ialah one-group pretest-posttest design yaitu memberikan pretest sebelum diberi perlakuan dan posttest setelah diberi perlakuan. Hasil perlakuan dapat diketahui lebih akurat karena dapat membandingkan dengan keadaan sebelum diberi perlakuan. Penelitian ini melibatkan dua kelompok eksperimen yaitu kelompok satu (I) dan kedua (II), pada kelompok eksperimen satu diberi perlakuan dengan menggunakan Model Direct Instruction dan kelompok eksperimen kedua menggunakan model Inkuiri.

\section{Populasi dan Teknik Pengambilan Sampel}

\section{Populasi}

Menurut Sugiyono (2016: 61) Populasi adalah wilayah generalisasi yang terdiri atas obyek/ subyek yang mempunyai kualitas dan karakteristik tertentu yang ditetapkan oleh peneliti untuk dipelajari dan kemudian ditarik kesimpulannya. Jadi populasi bukan hanya orang, tetapi juga obyek dan bendabenda alam yang lain. Populasi juga bukan sekesar jumlah yang ada pada obyek/subyek yang dipelajari, tetapi meliputi seluruh karakteristik/sifat yang dimiliki oleh subyek atau obyek yang diteliti itu. Selain itu, Arikunto (2017:173), menyatakan bahwa, "Populasi adalah keseluruhan subjek penelitian.Apabila seseorang ingin meneliti semua elemen yang ada dalam wilayah penelitian, maka penelitiannya merupakan penelitian populasi."Berdasarkan beberapa pendapat para ahli di atas, dapat disimpulkan bahwa populasi adalah seluruh subjek yang terdapat diwilayah penelitian yang dijadikan sebagai subjek yang ingin diteliti.

\section{Sampel}

Sampel adalah sebagian dari jumlah dan karakteristik yang dimiliki oleh populasi tersebut, ataupun bagian kecil dari anggota populasi yang diambil 
menurut prosedur tertentu. Sugiyono (2016:215) Sampel adalah sebagian dari populasi itu, populasi itu misalnya penduduk diwilayah tertentu, jumlah pegawai pada organisasi tertentu, jumlah guru dan murid disekolah tertentu dan sebagainya. Arikunto (2017:174) berpendapat bahwa sampel adalah sebagaian atau wakil populasi yang diteliti, dinamakan penelitian sampel apabila kita bermaksud untuk menggeneralisasikan hasil penelitian sampel. Berdasarkan beberapa pendapat para ahli di atas sampel adalah sebagian dari jumlah yang dimiliki oleh populasi, ataupun bagian kecil dari anggota populasi yang diambil menurut prosedur tertentu sehingga dapat mewakili populasinya.

Teknik pengambilan sampel pada penelitian ini menggunakan sampling purposive yaitu anggota populasi bersifat homogen. Berdasarkan pendapat di atas maka sampel yang digunakan dalam penelitian ini adalah seluruh siswa kelas $\mathrm{V}$ yang berjumlah 66 orang siswa. Dimana 66 orang siswa ini berasal dari dua ruang kelas.

\section{Jenis dan Sumber Data}

Menurut Sugiyono (2017:193), “sumber primer adalah sumber data yang langsung memberikan data kepada pengumpul data, dan sumber sekunder merupakan sumber yang tidak langsung memberikan data kepada pengumpul data, misalnya lewat orang lain atau lewat dokumen." Jadi, jenis data dalam penelitian ini berupa data primer yakni, hasil tes belajar siswa yang dilakukan peneliti langsung pada kelas yang sama tetapi mendapatkan dua perlakuan, sehingga peneliti mendapatkan hasil tes dengan materi perubahan sifat benda secara objektif. Atau dengan kata lain, sumber data dalam penelitian ini diperoleh langsung dari 66 orang siswa kelas V SDN 101816 Pancur Batu yang dijadikan sampel.

\section{Teknik dan Alat Pengumpulan Data}

Menurut Sugiyono (2017:308) Teknik pengumpulan data merupakan langkah yang paling utama dalam penelitian, karena tujuan utama dari penelitian adalah mendapatkan data. Tanpa mengetahui teknik pengumpulan data, maka peneliti tidak akan mendapatkan data yang memenuhi standar data yang ditetapkan. Menurut Arikunto (2017:266) mengumpulkan data merupakan 
pekerjaan yang penting dalam meneliti. Dalam penelitian ini peneliti menggunakan tes sebagai alat pengumpulan data.

Instrumen yang berupa tes ini dapat digunakan untuk mengukur kemampuan dasar dan pencapaian atau prestasi. Untuk mengukur kemapuan dasar antara lain : tes untuk mengukur intelegensi (IQ), tes minat, tes bakat khusus, dan sebagainya. Khusus untuk tes prestasi belajar yang biasa digunakan di sekolah dapat dibedakan menjadi dua yaitu :

a. Tes buatan guru

Tes buatan guru yang disusun oleh guru dengan prosedur tertentu tetapi belum mengalami uji coba berkali-kali sehingga tidak diketahui ciri-ciri dan kebaikannya.

b. Tes terstandar

Tes terstandar (standardized test) yaitu tes yang biasanya sudah tersedia di lembaga testing, yang sudah terjamin kemapuhannya. Tes terstandar adalah tes yang sudah mengalami uji coba berkali-kali, direvisi berkali-kali sehingga sudah dapat dikatakan cukup baik. Di dalam setiap tes yang terstandar sudah dicantumkan : petunjuk pelaksanaan, waktu yang dibutuhkan, bahan yang tercakup, dan hal-hal lain, misalnya validitas dan realibilitas.

Tes yang diberikan kepada siswa sesuai dengan materi Benda dan Sifatnya Direct Instruction dengan model Inkuiri di kelas V SDN 101816 Pancur Batu tahun pembelajaran 2018/2019. Terdapat dua hal utama yang mempengaruhi kualitas data hasil penelitian, yaitu, kualitas instrumen penelitian, dan kualitas pengumpulan data. Menurut Sugiyono (2016:137), kualitas instrumen penelitian berkenaan dengan validitas dan reliabilitas instrumen dan kualitas pengumpulan data berkenaan cara-cara yang digunakan untuk mengumpulkan data.

\section{Instrumen dan Uji Kualitas Instrumen}

\section{Instrumen Penelitian}

Instrumen penelitian atau alat pengumpulan data merupakan suatu alat untuk memperoleh data. Alat ini harus dipilih sesuai dengan jenis data yang diinginkan penelitian. Menurut Arikunto (2012:193-201), instrumen penelitian 
merupakan alat bantu yang dipilih dan digunakan oleh peneliti dalam melakukan kegiatan untuk mengumpulkan data agar kegiatan tersebut menjadi sistematis dan dipermudah olehnya. Instrumen penelitian merupakan alat ukur yang digunakan untuk mendapatkan informasi kuantitatif tentang variabel yang berkarakter dan objektif.

Tes merupakan alat ukur yang diberikan kepada individu untuk mendapatkan jawaban-jawaban yang diharapkan, baik secara tertulis maupun lisan. Tes yang digunakan oleh peneliti adalah tes pilihan berganda untuk dapat mengukur kemampuan pemahaman 66 orang siswa terhadap aktivitas pembelajaran yang terlaksana. Dan untuk mengolah skor dalam tes dalam bentuk pilihan berganda digunakan rumus sebagai berikut :

$S=R-\frac{W}{0-1} \quad$ (Arikunto,2016:187)

Keterangan:

$\mathrm{S} \quad=$ skor yang diperoleh

$\mathrm{R} \quad=$ jawaban yang betul

$\mathrm{W} \quad$ = jawaban yang salah

0 = banyaknya option

1 = bilangan tetap

Untuk mengetahui dan mengukur tes yang valid dan reliabel, maka peneliti menyajikan tes pilihan berganda yang untuk 66 orang siswa dengan materi Benda dan Sifatnya. Adapun kisi kisi soal ini berpanduan terhadap taksonomi bloom yaitu $\mathrm{C} 1$ (mengingat), $\mathrm{C} 2$ (memahami),C3(menerapkan), $\mathrm{C} 4$ (menganalisis), C5(mengevaluasi) dan C6(berkreasi). Dalam kisi-kisi soal ini, peneliti hanya menggunakan C1 sampai C4.

\section{Uji Kualitas Instrumen}

\section{Validitas}

Validitas data merupakan derajat ketepatan antara data yang terjadi pada objek penelitian dengan daya yang dilaporkan oleh peneliti. Validitas berkenaan dengan ketetapan alat penilaian terhadap konsep yang dinilai sehingga betul-betul menilai apa yang seharusnya dinilai. 
Uji validitas dalam penelitian ini menggunakan bantuan program SPSS (Statistical Program for Social Science) versi 23.0. Untuk mengetahui apakah instrumen yang digunakan valid atau tidak, maka (r) yang telah dihitung ( $\mathrm{r}_{\text {hitung }}$ ) dikonsultasikan dengan $\left(\mathrm{r}_{\text {tabel }}\right)$ product moment dengan taraf $5 \%$. Apabila $\mathrm{r}_{\text {hitung }}>$

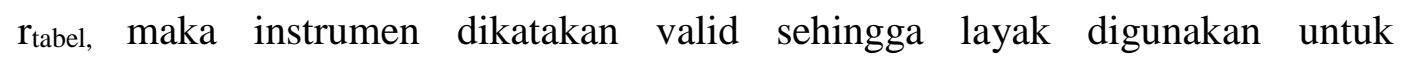
pengambilan data penelitian. Sebaliknya jika $r_{h i t u n g}<r_{\text {tabel }}$ maka instrumen tersebut tidak valid sehingga tidak layak digunakan untuk pengambilan data dalam penelitian.

Berdasarkan hasil uji validitas yang diolah dengan menggunakan SPSS ver 23 dan dapat dilihat pada tabel Item- Total Statistic kolom Corrected Item-Total Correlation diketahui bahwa 35 butir soal yang di uji cobakan pada 35 siswa di sekolah lain yaitu SD Fransiskus Xaverius Namorambe. Dari hasil uji coba tersebut terdapat 20 butir soal yang valid dan 15 butir soal yang tidak valid. Butir soal yang tidak valid tersebut cukup dihapus dan tidak perlu diganti, karena tanpa butir soal yang tidak valid sudah memenuhi indikator yang ada.

Selain dengan program SPSS untuk menguji validasi instrumen juga dapat dilakukan dengan menggunakan rumus pearson/product moment, yaitu (Arikunto,2016:95)

$\mathbf{r}_{x y}=\frac{n \sum X Y-\left(\sum X\right)\left(\sum Y\right)}{\sqrt{\left(n \sum X^{2}-\left(\sum X\right)^{2}\right) \cdot\left(n \sum Y^{2}-\left(\sum Y\right)^{2}\right)}}$

keterangan :

$\mathrm{r}_{x y}=$ koefisien korelasi antara variabel $\mathrm{X}$

$\mathrm{X}=$ skor item butir soal

$\mathrm{Y}=$ jumlah skor total tiap soal

$\mathrm{N}=$ jumlah responden

\section{Reliabilitas}

Instrumen yang reliabilitas adalah instrumen yang bila digunakan beberapa kali untuk mengukur objek yang sama, akan menghasilkan data yang sama (Sugiyono, 2014:168). Artinya instrumen dikatakan reliabel apabila digunakan 
berkali-kali untuk mengukur tetap menghasilkan data yang sama. Perhitungan uji realibilitas soal menggunakan SPSS versi 23.

Menurut Asnarni Lubis, langkah-langkah uji realibilitas yaitu pilih Analyze - Scale - Reliability Analysis. Pada kotak dialog Reliability Analysis, item-item yang valid dimasukkan pada kotak items. Selanjutnya pada statistic pada bagian Descriptive for pilih Scale if item Deleted kemudian Countinue, pada Model pilih Alpha lalu $O k$.

\section{Teknik Pengolahan (Analisis) Data}

Pengolahan data adalah suatu proses dalam memperoleh data ringkasan atau angka ringkasan dengan menggunakan cara-cara atau rumus-rumus tertentu. Pengolahan data bertujuan mengubah data mentah dari hasil pengukuran menjadi data yang lebih halus sehingga memberikan arah untuk pengkajian lebih lanjut.

Teknik pengelolaan data yang digunakan pada penelitian ini adalah telah dijelaskan bahwa hasil dan proses belajar tidak hanya bisa diukur dengan tes, tetapi juga dengan alat-alat ukur bukan tes seperti wawancara dan observasi. Dalam mengolah data hasil dari non tes, disamping digunakan cara-cara seperti pada pengolahan data yang menggunakan tes (terutama jika datanya bersifat interval dalam bentuk skor nilai), juga dapat digunakan cara-cara lain seperti persen, modus, peringkat, terutama bila hasil pengukuran menghasilkan data nominal atau ordinal Sudjana (2016:127).

1. Menyusun data postest dalam bentuk tabel.

2. Menghitung nilai rata-rata dan standar deviasi data sampel dari data postest.

3. Uji Normalitas

4. Uji Homogenitas

5. Uji hipotesis

\section{Prosedur Penelitian}

Prosedur penelitian ini dilakukan di sekolah SDN 101816 Pancur Batu sebagai tempat untuk meneliti. Adapun tahap-tahap dalam melakukan prosedur dalam penelitian ini adalah sebagai berikut:

1. Tahap Pembuatan Rancangan Penelitian (Tahap Perencanaan) 
Pada tahap ini peneliti mempersiapkan semua bahan untuk kegiatan pembelajaran seperti Rencana Pelaksanaan Pembelajaran (RPP), materi yang akan diajarkan, model yang digunakan oleh peneliti adalah infokus,laptop, serta buku pembelajaran IPA yang sesuai dengan materi yang akan diajarkan oleh peneliti.

2. Tahap Pelaksanaan Penelitian

Pada tahap ini berhubungan dengan kegiatan yang dilakukan di dalam kelas.Tahap tersebut dapat dilakukan seperti di bawah ini.

1) Mengajarkan materi pembelajaran tentang Benda dan Sifatnya dengan menggunakan model Direct Instruction dengan model inkuiri Dalam hal ini, yang perlu dilakukan oleh peneliti adalah mengajarkan dan memperjelas materi pembelajaran yang akan berlangsung tentang benda dan sifatnya. Setelah itu, guru dan siswa sama-sama mengoreksi soal yang sudah dikerjakan tersebut.

2) Menyuruh dan menugaskan siswa dalam menyelesaikan tes tentang Benda dan Sifatnya untuk nilai posttest. Di mana siswa menuliskan nama dan kelas pada tugas yang akan mereka kerjakan, dan guru memberikan waktu kepada siswa untuk mengerjakan soal tentang benda dan sifatnya. Setelah selesai mengerjakan tugasnya guru menyuruh siswa untuk mengumpulkan ke depan.

3. Tahap Penyelesaian

Pada tahap ini, peneliti menilai hasil kerja siswa dalam materi Benda dan Sifatnya dengan menggunakan penilaian posttest.

\section{HASIL PENELITIAN DAN PEMBAHASAN}

Mata pelajaran IPA merupakan salah satu mata pelajaran pokok di sekolah. Dalam pelaksanaannya di sekolah, agar guru dapat mengetahui jumlah siswa yang sudah memahami dan belum memahami pelajaran maka, dibuatlah standar yang harus dicapai oleh siswa sebagai syarat ketuntasan dalam pembelajaran yang telah dilaksanakan. Standar ketuntasan sering disebut dengan KKM (Kriteria Ketuntasan Minimal), setiap sekolah memiliki KKM yang berbeda 
di setiap mata pelajaran. Begitu juga dengan SDN 101816 Pancur Batu yang menetapkan nilai KKM mata pelajaran IPA adalah 65. Bagi siswa yang memperoleh nilai sama dengan 65 dan lebih dari nilai 65, maka siswa tersebut dinyatakan tuntas, namun sebaliknya bila siswa memperoleh nilai dibawah 65 maka siswa tersebut dinyatakan tidak tuntas. Berdasarkan nilai siswa kelas V SDN 101816 Pancur Batu pada mata pelajaran IPA dengan materi benda dan sifatnya nilai 60 diperoleh 1 siswa, nilai 65 diperoleh 6 siswa, nilai 70 diperoleh 10 siswa, nilai 75 diperoleh 9 siswa, nilai 80 diperoleh 4 siswa, nilai 85 diperoleh 3 siswa dan nilai 90 diperoleh 1 siswa. Dari data nilai kelas eksperimen I dapat disimpulkan bahwa nilai yang diperoleh siswa kelas V ada yang memenuhi KKM yang telah ditentukan yaitu 65. Nilai rata-rata yang diperoleh pada kelas eksperimen I yaitu 73,23.

Dengan menggunakan model pembelajaran Direct Instruction siswa tidak begitu termotivasi dan antusias dalam belajar. Hal ini disebabkan karena model pembelajaran ini bisa dikatakan biasa dilakukan disekolah, sehingga kebanyakan siswa kurang tertarik.

\section{Hasil Belajar IPA Menggunakan Model Inkuiri}

Berdasarkan hasil penelitian yang dilakukan oleh peneliti, terlihat bahwa nilai rata-rata hasil belajar siswa pada mata pelajaran IPA dengan menggunakan model pembelajaran Inkuiri oleh siswa kelas V SDN 101816 Pancur Batu adalah 86,56 digolongkan dalam kategori sangat baik, terlihat dari hasil belajar siswa yang diperoleh peneliti mencapai nilai KKM yang telah ditentukan oleh sekolah yaitu 65. Semua siswa di kelas eksperimen II melampaui KKM yang telah ditentukan.

Hasil yang diperoleh siswa di kelas eksperimen II ini dapat dijabarkan sebagai berikut : nilai 75 diperoleh 2 siswa, nilai 80 diperoleh 5 siswa, nilai 85 diperoleh 15 siswa, nilai 90 diperoleh 5 orang, nilai 95 diperoleh 1 orang, nilai 100 diperoleh 4 siswa. Hal tersebut dapat dilihat dari frekuensi penilaian jumlah yaitu sebanyak 30 siswa atau 78,1\% memperoleh nilai dalam rentang 85-100 
digolongkan dalam kategori sangat baik, 7 siswa atau 21,9 \% memperoleh nilai dalam rentang 75-84 digolongkan dalam kategori baik. Dalam kegiatan pembelajaran menggunakan model Inkuiri siswa sangat termotivasi dalam belajar sehingga hasil belajar yang diperoleh dapat tergolong tinggi. Hal ini disebabkan karena model pembelajaran ini sangat cocok digunakan pada materi benda dan sifatnya.

\section{PerbedaanPenerapan Model Direct Instruction dan Model Inkuiri}

Sesuai dengan hasil penelitian pada mata pelajaran IPA dengan menggunakan model pembelajaran inkuirisudah melewati nilai KKM yaitu 86,56. Dan hasil belajar IPA dengan menggunakan model pembelajaran Direct Instruction juga melewati KKM tetapi model Inkuiri yang lebih baik Berdasarkan hal tersebut maka dapat diketahui bahwa pembelajaran menggunakan model Inkuiri menunjukkan hasil belajar siswa lebih baik dibandingkan dengan pembelajaran yang menggunakan model pembelajaran Direct Instruction .

Perbedaan tersebut signifikan sehingga model pembelajaran Inkuiri dikatakan efektif untuk mata pelajaran IPA. Hal ini disebabkan karena model Inkuiri membuat siswa lebih aktif, sehingga setiap siswa mendapat materi sesuai dengan kehidupan nyata siswa yang berbeda dan tidak memiliki waktu untuk bermain dengan teman sehingga membuat siswa lebih menguasai materi pelajaran. Sedangkan model pembelajaran Direct Iinstruction dalam pembelajaran guru yang lebih aktif daripada siswanya.Sesuai dengan penelitian relevan yang dilakukan Yeti Nuryanti (2016) menyatakan bahwa model Inkuiri lebih efektif dibandingkan model Direct Instruction.

\section{PENUTUP}

\section{Simpulan}

Berdasarkan uraian yang telah dikemukakan pada bab sebelumnya, maka dapat dikemukakan beberapa simpulan dari penelitian ini yaitu: 
1. Nilai rata-rata yang diperoleh siswa SDN 101816 Pancur Batu tahun pembelajaran 2018/2019 dengan menggunakan model Direct Instruction adalah 73,23 berada dalam kategori cukup.

2. Sedangkan nilai rata-rata yang diperoleh siswa SDN 101816 Pancur Batu tahun pembelajaran 2018/2019 dengan menggunakan model Inkuiri adalah 86,56 berada dalam kategori sangat baik.

3. Bahwa model Inkuiri lebih efektif dibandingkan model Direct Instrucion dapat dilihat dari keaktifan siswa dalam proses pembelajaran. Keefektifan diantara kedua model tersebut menunjukkan bahwa model Inkuiri lebih baik dibandingkan dengan model Direct Instruction. Berdasarkan perhitungan dengan uji " $t$ " diperoleh $\mathrm{t}$ hitung $=7,949$. Sampel yang digunakan sebanyak 66 orang, $\mathrm{t}$ hitung > t tabel, 7,949>1,99 sehingga dapat disimpulkan bahwa $\mathrm{H}_{0}$ ditolak dan $\mathrm{H}_{1}$ diterima. Hal ini juga dibuktikan dari hasil temuan-temuan yang peneliti dapatkan dengan menerapkan model pembelajaran Inkuiri, model Inkuiri ini dapat meningkatkan hasil belajar siswa, menjadikan siswa lebih aktif, antusias dalam belajar, mengikuti pembelajaran dengan baik, dan dapat menjawab soal-soal evaluasi yang diberikan guru dengan cepat dan tepat.

\section{Saran}

Berdasarkan pembahasan dari kesimpulan, implikasi dan keterbatasan penelitian di atas maka peneliti memberikan beberapa saran yaitu:

1. Kemampuan siswa perlu ditingkatkan lagi. Hal tersebut tentunya membutuhkan model pembelajaran yang lebih efektif untuk digunakan dalam belajar mengajar di sekolah. Salah satu model pembelajaran yang dapat dijadikan sebagai alternatif adalah model pembelajaran Inkuiri.

2. Hasil penelitian diharapkan mampu menjadi pegangan bagi pelaku dalam bidang pendidikan untuk mencari alternatif model pembelajaran yang lebih baik yaitu dengan cara melakukan penelitian lanjutan dengan menggunakan model pembelajaran dan sistem mengajar yang lebih modern dan kreatif.

3. Guru hendaknya dapat menggunakan model pembelajaran yang bernilai efektif sesuai dengan materi pelajaran yang disampaikan, sehingga siswa 
merasa tidak dibebani oleh model ataupun metode yang menyebabkan ia merasa jenuh dan bosan ketika mengikuti kegiatan pembelajaran.

4. Kepala sekolah sebagai tempat atau wadah mendidik agar lebih memperhatikan saran dan sistem pengajaran guna meningkatkan mutu pengajaran khususnya bidang mata pelajaran IPA.

\section{DAFTAR PUSTAKA}

Arikunto, Suharsimi. 2016. Dasar-Dasar Evaluasi Pendidikan. Jakarta:Bumi Aksara.

Jakarta:

2017. Prosedur Penelitian Suatu Pendekatan Praktik.

Rineka Cipta.

Hamdayama, Jumanta. 2016. Metodologi Pengajaran. Jakarta: Bumi Aksara.

Istarani dan Pulungan. 2015. Ekslopedia Pendidikan. Medan: Larispa.

Khoeriyah, Ni'matul. 2016. Pengaruh Model Direct Instruction Terhadap Hasil Belajar SBK

Materi Membuat Karya Kolase Siswa Kelas IV Sdn Gugus Kenanga Kabupaten Kebumen. Portal Garuda.

Kurniasih dan Sani. 2015. Ragam Pengembangan Model Pembelajaran untuk Peningkatan Profesionalitas Guru (Guru Inspiratif, Menjadi Guru Profesional, Pengembangan Model-Model Pembelajaran, Berbagai Macam Model Pembelajaran). Jakarta: Kata Pena.

Lubis, Asnarni. 2015. Statistik SPSS 23. Medan

Ngalimun. 2014. Strategi dan Model Pembelajaran.Yogyakarta : Aswaja Pressindo

Nurhayat. 2016. Perbandingan Model KooperatifTipe Two Stay Two Stray Dan Think Pair Share Terhadap Hasil Belajar IPS SiswaKelas V SD Negeri 10 Metro Pusat. Portal Garuda

Nuryanti,Yeti. 2016. Pengaruh Penggunaan Model Inkuiri Terhadap Hasil Belajar IPA Ranah Kognitif Siswa Kelas IV Sd Negeri 1 Kampung Baru. Portal Garuda.

Rohani. 2014.Peningkatan Hasil Belajar Melalui Strategi Pembelajaran Langsung (Direct Instruction) Mata Pelajaran Bahasa Indonesia SDN 167644 Kota Tebing Tinggi . Portal Garuda. 
Rohmah, Ulfatun. 2013. Penerapan Metode Inkuiri Dalam Peningkatan Pembelajaran IPA Siswa Kelas IV Sekolah Dasar. Portal Garuda.

Shoimin. 2014. 68 Model Pembelajaran Inovatif dalam Kurikulum 2013.Yogyakarta: Ar-Ruzz Media.

Suardika. 2013. Pengaruh Perbedaan Antara Model Pembelajaran Inkuiri Terbimbing Dan Model Pembelajaran Langsung Terhadap Penguasaan Konsep IPA Kelas V Di Gugus III. Portal Garuda.

Sudjana, Nana. 2016. Penilaian Hasil Proses Belajar Mengajar. Bandung: PT Remaja Rosdakarya Offset.

Sudijono, Anas. 2017. Pengantar Statistika Pendidikan. Jakarta: PT Raja Grafindo Persada.

Sugiyono. 2016. Metode Penelitian Pendidikan Kuantitatif, Kualitatif, dan R\&D. Bandung: Alfabeta. 2016. Satistika untuk Penelitian. Bandung : Alfabeta

Susanto, Ahmad. 2012. Teori belajar \& Pembelajaran di sekolah Dasar. Jakarta: Kencana Prenada Media Group.

Tampubolon, Saur. 2014. Penelitian Tindakan Kelas Sebagai Pengembangan Profesi Pendidik Dan Keilmuan. Jakarta : Erlangga.

Trianto. 2009. Mendasain Model - Model Pembelajaran Inovatif Progresif.Jakarta: Kencana Prenada Media Group.

Undang- Undang Repbulik Indonesia. Nomor 20 Tahun 2003. Tentang Sistem Pendidikan Nasional. 